\title{
Estimating the Effect of Precipitation and Vegetation on Water Yield in Northern China
}

\author{
Chen Shi ${ }^{1}$, Shibao Yuan ${ }^{2}$, Changqing Shi ${ }^{1}$, Tingning Zhao ${ }^{1 *}$ \\ ${ }^{1}$ School of Soil and Water Conservation, Beijing Forestry University, 100083, Beijing, China \\ ${ }^{2}$ Beijing Municipal Bureau of Landscape and Forestry, 100013, Beijing, China
}

Received: 24 April 2017

Accepted: 11 July 2017

\begin{abstract}
This study attempts to analyze how precipitation and vegetation affect water yield in Haihe watershed. Based on the annual runoff and meteorological data, the water balance equation and the calibrated Zhang model were used to simulate the effects of precipitation and vegetation on water yield. The simulated results showed that the effect of precipitation on water yield was linear in mountainous area of Haihe watershed, and a $1 \mathrm{~mm}$ change (increase or decrease) in precipitation will cause a $0.51 \mathrm{~mm}$ change in water yield; under the mean annual precipitation of $534 \mathrm{~mm}$, the effects of decreasing water yield by per unit cover ratio for forest, grassland, and farmland were $1.26,0.47$, and $0.69 \mathrm{~mm}$, respectively. The decreased water yields for forest, grassland, and farmland were associated with aridity indexes by negative power functions, and indicate that the effect of vegetation on water yield was smaller in drier areas. For three vegetation types the effects of vegetation on water yield were similar for crops and grass, and were much larger for forest.
\end{abstract}

Keywords: precipitation, vegetation, water yield, northern China

\section{Introduction}

The effect of vegetation on water yield is a popular and important issue in ecohydrological studies. In response to the widely observed degradation of formerly forested land and the rising demands for paper pulp, industrial wood, and wood fuel, the need for large-scale reforestation programs has been expressed repeatedly. To address the increasing levels of soil erosion and desertification, China has implemented many large-scale reforestation programs in recent decades [1]. While creating many economic and ecological benefits, reforestation could also

*e-mail: zhtningbjfu@163.com potentially reduce water capacity [2-3]. Because of this, correct understanding of the forest-water relationship is particularly important.

There have been many influential studies made in understanding forest and water relationships during the past century around the globe. Our understanding of the forest impact on annual water yield is well advanced and there are robust methods available for predicting the impact of forest change on the mean annual water balance [4]. Methods have also been established that allow the prediction of water yield changes in response to forest change at the annual time scale [5-6].

Although researchers concurred with that forests decrease water yield, the decreasing extent is different. Farley et al. (2005) made a global analysis using 26 
catchment datasets and 504 observations, found that the annual water yield was reduced by $44 \%$ and $31 \%$ when grasslands and shrublands, respectively, were afforested [7]. Sun et al. (2006) examined the sensitivity of water yield responding to forestation across China, then recorded that the reduction in water yield due to forestation varied from about $50 \mathrm{~mm} / \mathrm{yr}$ (50\%) in the semi-arid Loess Plateau in mountainous area of Haihe watershed to about $300 \mathrm{~mm} / \mathrm{yr}(30 \%)$ in the tropical southern region [8]. Wang et al. (2011), using published literature data from the past 50 years, showed that the regional average of annual runoff for forest is only $16 \mathrm{~mm}-58 \%$ lower than the $39 \mathrm{~mm}$ for non-forestland [9]. These findings indicate that the effects of vegetation can vary with climate and/or geography.

Evapotranspiration is the main process responsible for changes in mean annual water yield in response to alterations in vegetation [10-12]. Zhang et al. (2001) analyzed results from 250 catchments worldwide [13]. They developed a simple two-parameter model to estimate mean annual evapotranspiration at catchment scale. This model allowed for simulation of the effects of precipitation and different vegetation.

The Haihe watershed is the largest water system in northern China and covers the fastest growing economic region of China [14]. This region is also densely populated, highly developed, and the most water-scarce region in China. It has been transferring real water from outside through various water diversion projects [15]. In recent years, the ecological environment of the watershed has been severely damaged as a shortage of water resources and a series of ecological environmental problems have made the region the most prominent contradiction between water and humanities in China [16]. A study of changes in water yield in this region thus has an important practical significance.

The objectives of our study were to:

1. Analyze the quantitative effect of precipitation on water yield.

2. Estimate the effects of forestland, grassland, and farmland on decreasing water yield.

3. Investigate the effects of vegetation on water yield with consideration of aridity indices.

\section{Material and Methods}

\section{Study Area}

The study was carried out in the mountainous areas in Haihe watershed, which is bound by latitude $35^{\circ} 4^{\prime}$ and $44^{\circ} 11^{\prime}$ and longitude $111^{\circ} 41^{\prime}$ and $120^{\circ} 17^{\prime}$ (Fig. 1). The areal coverage of watershed is $31.82 \times 10^{4} \mathrm{~km}^{2}$ and selected mountainous area $26.48 \times 10^{4} \mathrm{~km}^{2}$. The topography is characterized by low mountains and hilly landscapes, with elevation varying from 1 to $2,940 \mathrm{~m}$ above sea level. The soil layer is $30 \sim 80 \mathrm{~cm}$. The main land use types in the study area were forest, grass, and crop, accounting for $31.82 \%, 31.41 \%$, and $32.06 \%$, respectively. The principal

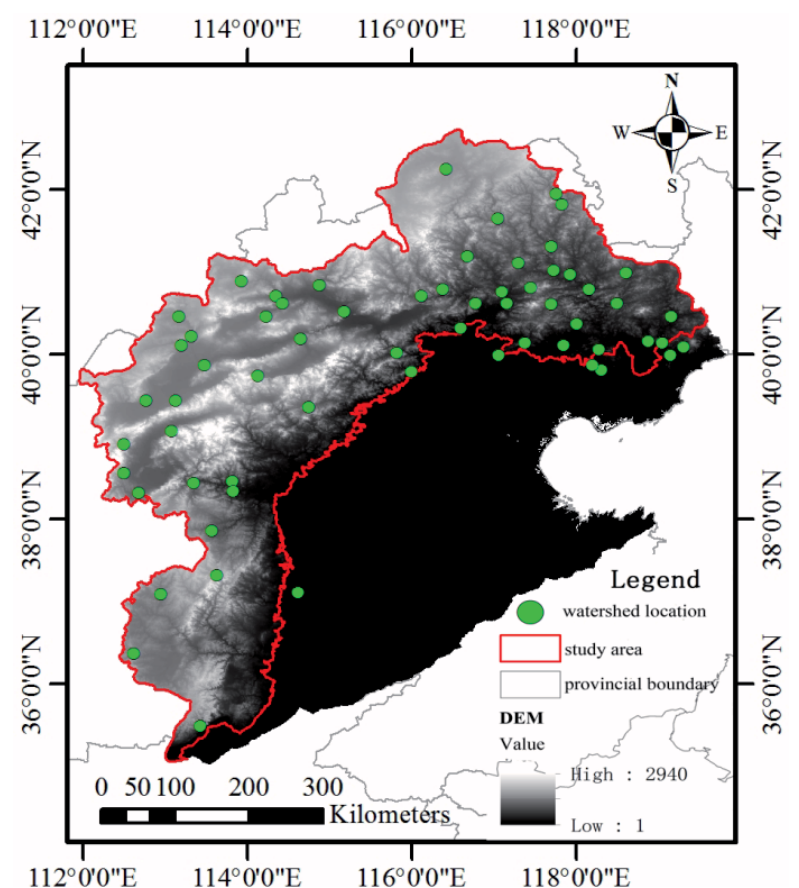

Fig. 1. Location of study area and catchment outlets.

species of forest were Pinus tabulaeformis, Platycladus orientalis, and Quercus variabilis; principal species of grass were Gramineae, Cyperaceae, and Compositae; and the principal species of crop were Zea mays L. and Triticum aestivum L.

The region has a semi-humid continental monsoon climate with a mean annual temperature of $12^{\circ} \mathrm{C}$. Precipitation is highly variable, both spatially and temporally, in the range $350-800 \mathrm{~mm}$. More than $85 \%$ of the rain falls between June and October.

\section{Data}

Annual precipitation and runoff were obtained from the Hydrological Yearbook of PR China (196091). Meteorological data were obtained from the China Meteorological Data Sharing Service System (data.cma.cn/en). The digital elevation model (DEM) of this region, with a resolution of $90 \times 90 \mathrm{~m}$, was used to delineate the catchment boundaries of all catchments. The DEM and forest cover data were both derived from Data Sharing Infrastructure of Earth System Science (www. geodata.cn).

\section{Methods}

Water balance provides a common framework for studying hydrological behavior in watershed scale, and it can be expressed as:

$$
P=E T+R+D+\Delta S
$$

...where $P$ is mean annual precipitation (MAP) (mm), ET is mean annual evapotranspiration of a watershed ( $\mathrm{mm})$, 
$R$ is mean annual runoff (MAR) (mm), $D$ is groundwater recharge, and $\Delta S$ is the change in soil moisture. $D$ and $\Delta S$ can be considered to be 0 for a sufficiently long time series ( $>10$ years) (Zhang et al. 2007). This formula can then be simplified as:

$$
P=E T+R
$$

By analyzing results from 250 catchments worldwide, Zhang et al. (2001) developed a simple two-parameter model to estimate mean annual evapotranspiration at the catchment scale [13]. Evapotranspiration can be described and estimated by:

$$
\frac{E T}{P}=\frac{1+\omega \frac{E_{0}}{P}}{1+\omega \frac{E_{0}}{P}+\left(\frac{E_{0}}{P}\right)^{-1}}
$$

...where $E_{0}(\mathrm{~mm})$ is potential evapotranspiration and $\omega$ is the plant available water coefficient, which represents the relative difference in the way plants use soil water for transpiration.

Sun et al. (2005) developed this model for catchments with mixed land use [17]:

$$
E T=\sum\left(E T_{i} \times f_{i}\right)
$$

...where $f_{i}$ is the percentage of land use $i$, including forestland, grassland, farmland, bare land, water bodies, and residential lands.

Potential evapotranspiration $\left(\mathrm{E}_{0}\right)$ is closely associated with temperature, solar radiation, and other meteorological factors, and varies widely in different watersheds. The potential evapotranspiration $\left(\mathrm{E}_{0}\right)$ is calculated as:

$$
\begin{gathered}
E_{0}=\alpha \frac{\Delta}{\Delta+\gamma} R_{n} \\
\Delta=2503 \frac{e^{\frac{17.27 T}{T+237.3}}}{(T+237.3)^{2}}
\end{gathered}
$$

...where $\alpha$ is a constant equal to $1.28, \Delta$ is the slope of the saturation vapor pressure curve, $\gamma$ is the psychrometric constant, $T$ is the daily mean air temperature, and $R_{n}$ is total net radiation.

The main land use types in mountainous area of Haihe watershed are forestland, grassland, farmland, bare land, and residential land. In simulations of the Zhang model, the three main model parameters are $\mathrm{P}, \mathrm{E}_{0}$, and $\omega$ (Eq. 3). To extend the model to catchments with various land uses, Zhang et al. (2001) assumed that annual evapotranspiration of a catchment was the sum of forested and non-forested land, and simply represented non-forested land as grassland [13]. Land use in the study area is very complex, however, so the simple representation of non-forested land as grass is not appropriate. We thus had to calibrate $\mathrm{E}_{0}$ with Eq. 5 for the different land uses before we could use the Zhang model.

In statistics, the mean absolute error (MAE) is a quantity used to measure how close forecasts or predictions are to the eventual outcomes. The mean absolute error is given by:

$$
M A E=\frac{1}{n} \sum_{i=1}^{n}\left|x_{i}-y_{i}\right|
$$

...where $x_{i}$ is the prediction, $y_{i}$ is the true value, and $n$ is the sample size.

\section{Results and Discussion}

\section{Fitting Model Parameters}

Potential evapotranspiration was calculated with Eq. 5 using long-term (1960-90) meteorological data for each of the 50 national weather stations within or around the study area. Among the 21 stations within the study area, 14 were surrounded by farmland, four were surrounded by grassland, and three were surrounded by forests. The potential evapotranspiration of forest, grassland, and farmland was calculated from the mean values of these stations, respectively. No weather stations were surrounded by bare land, water bodies, or residential land, so we simulated the potential evapotranspiration of the study area (Fig. 2) by Kriging interpolation

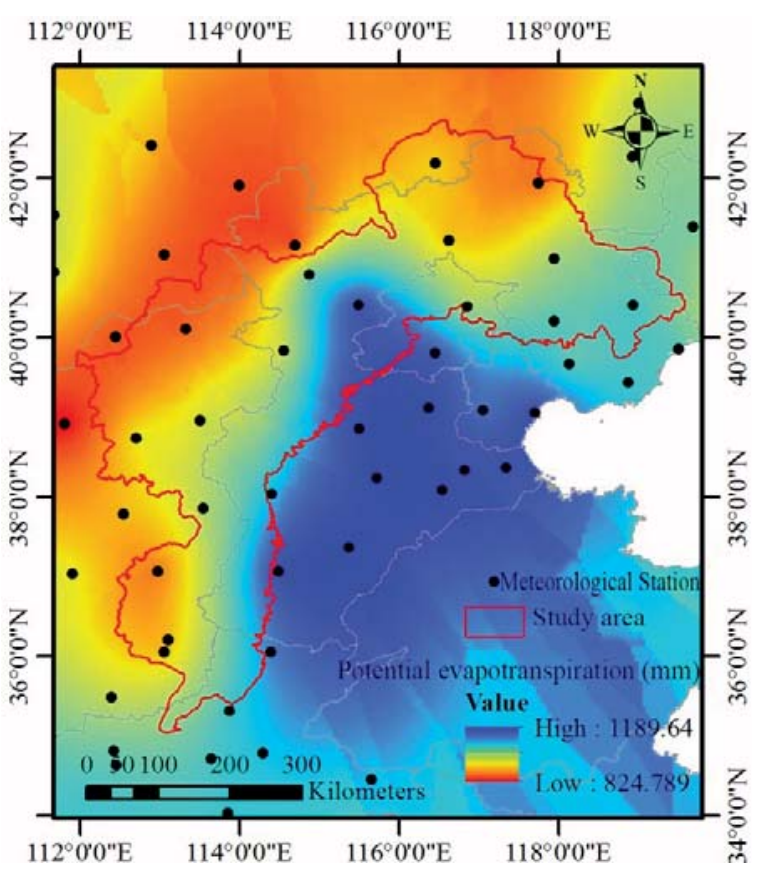

Fig. 2. Potential mean annual evapotranspiration in mountainous area of Haihe watershed. 


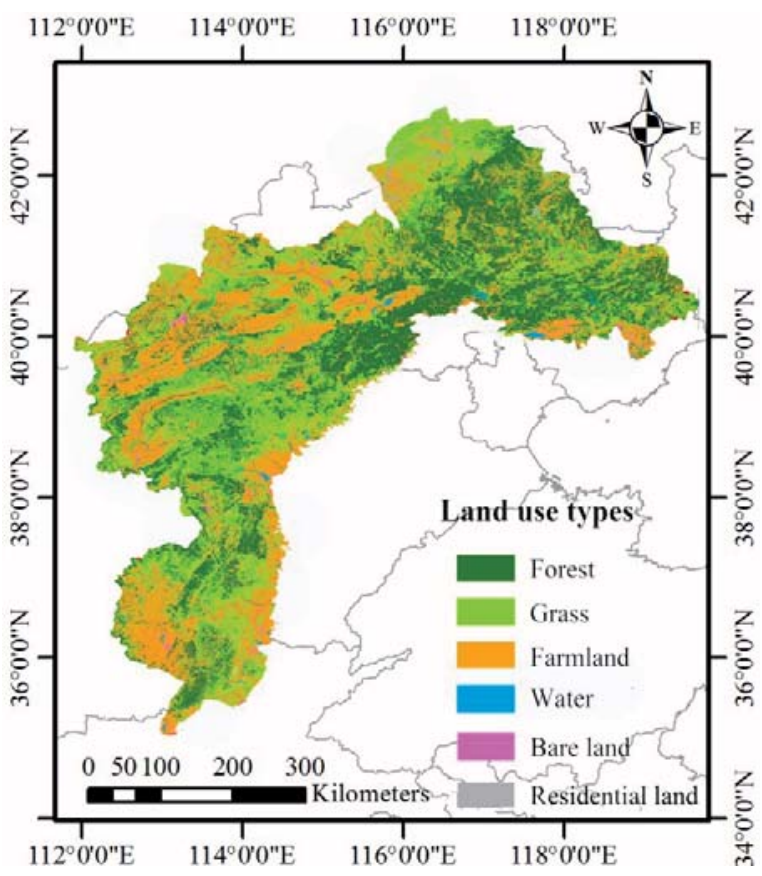

Fig. 3. Land use types of mountainous area of Haihe watershed.

using ArcGIS software, and then extracted the potential evapotranspiration for these three land use types by using the land use map (Fig. 3).

According to Zhang et al. (2001), the best fit values of $\omega$ is 2.0 for forest, 0.5 for grass and crop, and $<0.5$ for bare soil. To best fit the $\omega$ values to study region, we tested each group $\omega$ from 1.5 to 2.5 for forest, from 0.1 to 1.0 for grass or crop, and from 0.0 to 0.5 for bare and residential land. The best simulations were for $\omega$ values of 2.0 for forest, 0.6 for grass/crop, and 0.1 for bare/residential land. The derived values of $\mathrm{E}_{0}$ and $\omega$ for the mountainous area of Haihe watershed are shown in Table 1.

Fig. 4 shows the comparison of measured and simulated evapotranspiration values using the calibrated parameters and the Zhang model for the 32 watersheds. Linear regression analysis indicated that the measured and simulated data were highly correlated $\left(R^{2}=0.89\right.$, $P<0.001)$, the slope of the regression line is 0.98 , which is close to 1; the mean absolute error (MAE) (Eq. 7) between the model estimates and the measurements was $20.84 \mathrm{~mm}$, or $4.70 \%$ of the mean annual ET. Thus the calibration of

Table 1. Calibrated parameters of the Zhang model.

\begin{tabular}{|c|c|c|}
\hline Land use types $(i)$ & $\mathrm{E}_{0} / \mathrm{mm}$ & $\omega$ \\
\hline Forest & 1,000 & 2.0 \\
\hline Grass & 960 & 0.6 \\
\hline Farmland & 980 & 0.6 \\
\hline Bare land & 910 & 0.1 \\
\hline Residential land & 920 & 0.1 \\
\hline Water bodies & 1,150 & - \\
\hline
\end{tabular}

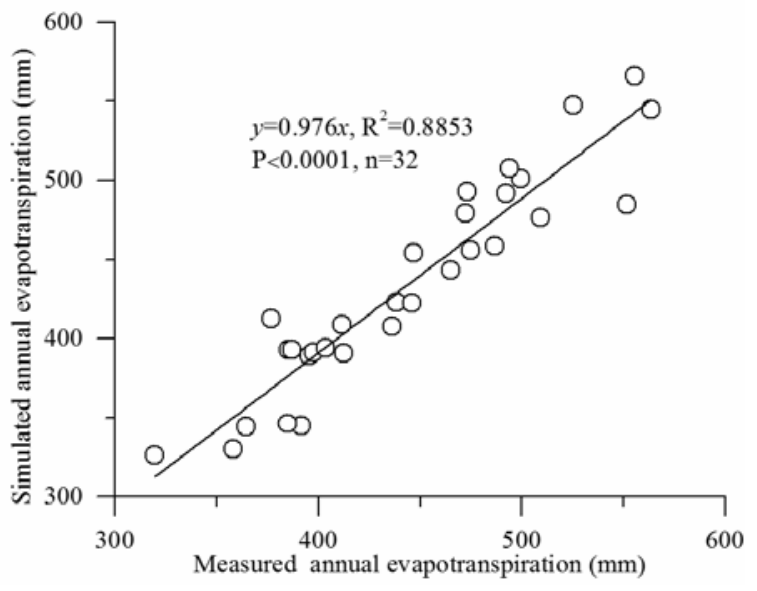

Fig. 4. Model calibration: correlations between simulated and measured annual evapotranspiration for 32 catchments.

the model parameters $\left(\mathrm{E}_{0}\right.$ and $\left.\omega\right)$ was good, and these parameters could be used in subsequent simulations.

\section{Effects of Precipitation on Water Yield}

Precipitation is the main source of water yield and also the most important influencing factor. The mean annual precipitation in north China is $534 \mathrm{~mm}$. In this study, based on the Zhang model (Eq. 3) and water balance equations (Eq. 2), we thus used $534 \mathrm{~mm}$ to simulate the corresponding water yield of each catchment. The measured and simulated values in Fig. 5 show the response of water yield to variations in actual levels of precipitation from $534 \mathrm{~mm}$. In this figure, $\mathrm{x}$-axis showed the difference between actual precipitation and simulated precipitation of $534 \mathrm{~mm}$, and then $\mathrm{y}$-axis showed the difference between the actual streamflow in actual precipitation and the simulated streamflow in simulated precipitation at $534 \mathrm{~mm}$.

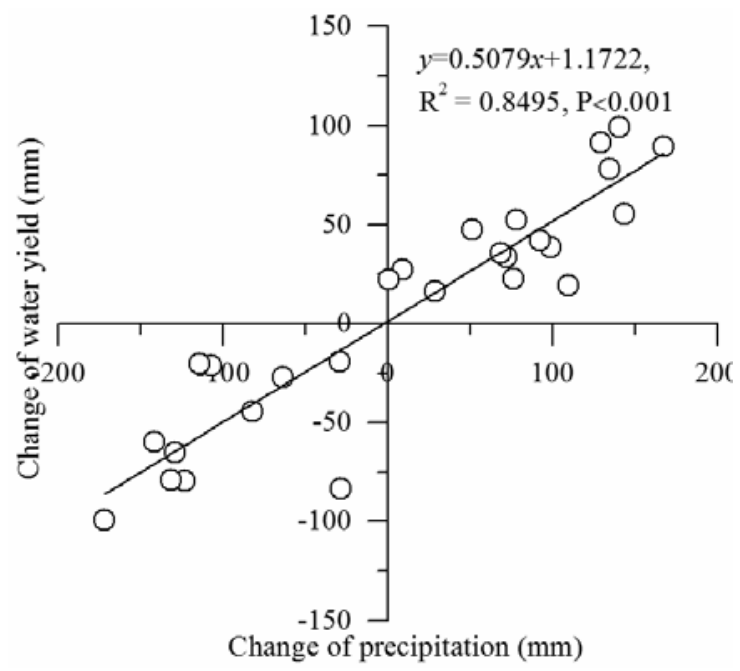

Fig. 5. Response of annual water yield caused by change of precipitation from actual to $534 \mathrm{~mm}$. 
Table 2. Correlations of precipitation and the water yield change of three vegetation types.

\begin{tabular}{|c|c|c|c|}
\hline & Forest & Grass & Crop \\
\hline Pearson correlation & $0.600^{* *}$ & $0.566^{* *}$ & $0.569^{* *}$ \\
\hline Sig. & 0.001 & 0.002 & 0.002 \\
\hline
\end{tabular}

**Correlation is significant at the 0.01 level

Fig. 5 shows the changes of water yield and precipitation with a good linear correlation (Table 2), and the equation for the regression line is $y=0.51 x+1.17$ $\left(R^{2}=0.85, P<0.001\right)$. The effect of precipitation on water yield was thus linear, the water yield increases/decreases linearly with increasing/decreasing precipitation. The slope of the fitting line was 0.51 , i.e. a $1 \mathrm{~mm}$ change (increase or decrease) in precipitation will cause about a $0.51 \mathrm{~mm}$ change (increase or decrease) in water yield.

Mean annual precipitation is one of the most important determinants of annual runoff and can have a strong influence on changes in runoff after a change in vegetation [18-20]. Amarasingha undertook a further review of paired catchments and concluded that changes in water yield were largest in areas with high rainfall [21]. Huxman Travis E. et al. also suggested that forests influenced evapotranspiration to a greater extent in more mesic climates and less so in arid climates [22]. In agreement with these previous analyses, our results show that the effects of three vegetation types on decreasing water yield all increased with precipitation and could be described by power functions $\left(Y=a x^{b}\right)$. Vegetation thus has a larger effect on water yield in areas with more precipitation. The negative power relationships $\left(Y=a x^{-b}\right)$ between the effects of vegetation and the aridity index also show that vegetation has a smaller effect on water yield in drier areas.

\section{Effects of Vegetation on Water Yield}

In this study, the effects of clear-cutting the vegetation (to become bare land) on water yields have been simulated by a reduction of the $\omega$ parameter from original value of different vegetation types to 0.0 , and the difference between the simulated and measured values indicated water yield's lowering effects of forest, grassland, or farmland on water yield [17]. The amount of water yield reduction was closely associated with the cover ratio of three vegetation types (Fig. 6).

The lowered water yields of these three vegetation types were well correlated linearly with their cover ratio $\left(R^{2}>0.70, P<0.001\right)$. The lowering effects of these vegetation types on water yield thus increased linearly with cover ratio. The slopes of the regression lines represent the lowering rate water yields $(\mathrm{mm})$ of per unit percentage $(1 \%)$, and we use them to reflect the sensitivity of vegetation on decreasing water yield. As seen from Fig. 6, the powers of grass and crop on decreasing water yield are approximately 0.47 and $0.69 \mathrm{~mm} / \%$, while the

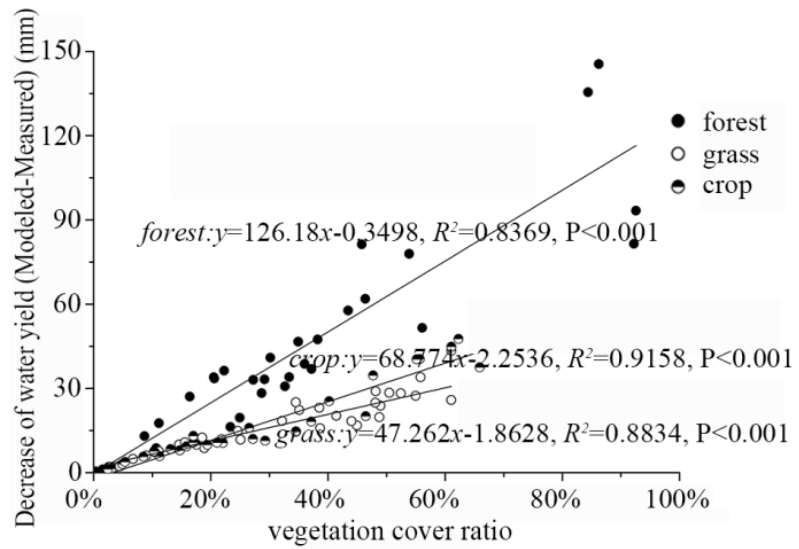

Fig. 6. Relationships between decreased water yield and vegetation cover ratio.

power of forest is $1.26 \mathrm{~mm} / \%$, much larger than the grass and crop. That means a $1 \%$ decrease in the cover ratio of forest, grass, and crop would increase water yield 1.26, 0.47 , and $0.69 \mathrm{~mm}$.

Zhao et al. illustrated that water yields changed following vegetation changes, and this process occurred not only in small catchments but also in larger watersheds [23]. In this study, of the three vegetation types (forest, grass, and crop), forest had a much larger effect on water yield than did the other two types. Forest have a higher capacity for water consumption, associated with the higher leaf area index (LAI) of the higher stature vegetation [24], and tend to have better access to water sources through accessing deep water or drawing on stored soil water [25]. Transpiration is traditionally considered the most important component of forest evapotranspiration, but interception and subsequent evaporation from the canopy can also increase substantially, particularly with conifers [26]. The evaporation of intercepted precipitation can account for $10-20 \%$ of the rainfall for broadleaf trees and $20-40 \%$ for conifers [27]. All these factors contribute to the larger effects of forests on water yield than the effects of grass and crop.

\section{Effects of Vegetation on Water Yield Considering Aridity Indices}

The aridity index, as a function of precipitation and potential evaporation $\left(\mathrm{E}_{0} / \mathrm{P}\right)$, represents the degree of drying in a region and can be used as a good representative indicator of climatic conditions [28-29]. Fig. 7 shows the variations of the affected water yields due to vegetation change of $1 \%$ with different values of the aridity index. The results show that the lower effects of three vegetation types on water yields are all decreased with the aridity index, and could be described by negative power functions $\left(Y=a x^{-b}\right)$, indicating that vegetation has less of an effect on water yield in drier areas. The effects of crop and grass were similar, and the effect of forest was much greater. 


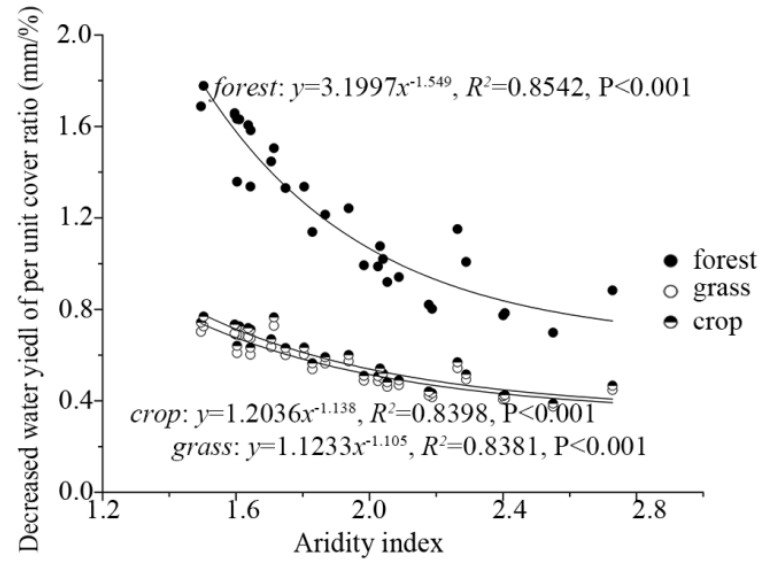

Fig. 7. Relationships between affected water yield and aridity index.

Many previous studies showed that the changes of streamflow were different in different regions and in different time scales, and especially for the effects of climate change. There was a finding of the previous studies that low-streamflow area was more sensitive to climatic variation than high-streamflow area. And the effect of vegetation, based on the Zhang model, was caused by their evapotranspiration, and had a close relationship with the climate.

Previous research indicated that the stage of forest development also affected water yield. In this study, the age of trees in the study area were mostly older than 50 years, and we also deliberately used the average values of the records of longer duration (10-31 years) in an attempt to minimize these errors, and this has already been a simple and effective approach.

In large forested watersheds, forest disturbance and climatic variability are commonly recognized as two major drivers interactively influencing hydrology in forested watersheds [30-31]. The biggest challenge is how to separate their relative contributions to hydrology [32-33]. And some hydrological modeling is often used to assess the relative effects of climate variability and forest change on hydrology [23]. But this modeling approach requires major efforts on model calibration and has uncertainties in the structure and parameters of the model, and is only applicable for the watersheds with long-term available data on vegetation, soil, topography, land use, hydrology, and climate [31]. In this study, we simply simulated the effects of vegetation on water yield with a given precipitation of the mean annual value of $534 \mathrm{~mm}$, and attempt to remove the disturbance of precipitation. And this might lead to some uncertainties.

\section{Conclusions}

The impact of vegetation manipulation on water yield was one of the important components in ecohydrological studies. However, the direction and magnitude of water yield change associated with vegetation has long been an issue of debate. Analyzing the effects of precipitation and vegetation on water yield could be helpful to understand the hydrological relationship between vegetation and water. In this study, we simulated their effects by using the water balance equation and the calibrated Zhang model and concluded that:

1. In this study area within certain precipitation, the effect of precipitation on water yield was linear, and a $1 \mathrm{~mm}$ change (increase or decrease) in precipitation would cause a $0.51 \mathrm{~mm}$ change (increase or decrease) in water yield.

2. With mean annual precipitation of $534 \mathrm{~mm}$ in the mountainous area of Haihe watershed, the effects of decreasing water yield by per unit cover ratio $(1 \%)$ for grassland and farmland were approximately 0.47 and $0.69 \mathrm{~mm}$, respectively, while the effect by per unit cover ratio (1\%) for forestland was $1.26 \mathrm{~mm}$ - much greater than grassland and farmland.

3. Vegetation had less effect in drier (larger aridity index) area; the effects of the three vegetation types were associated with aridity index by negative power functions $\left(Y=a x^{-b}\right)$; the effects of crop and grass were similar, and the effect of forest was much greater.

\section{Acknowledgements}

This research was financially supported by the entrusted project (2016HXFWSBXY014) of the Beijing Gardening and Greening Bureau.

\section{References}

1. YAO Y.F., CAI T.J., WEI X.H., ZHANG M.F., JU C.Y. Effect of forest recovery on summer streamflow in small forested watersheds, Northeastern China. Hydrological Processes. 26, 1208, 2011.

2. BATELIS S.C., NALBANTIS I. Potential Effects of Forest Fires on Streamflow in the Enipeas River Basin, Thessaly, Greece. Environmental Processes. 1, 73, 2014.

3. LOPES V.L., FFOLLIOTT P.F. Effects of Forest Harvesting Practices on Streamflow-Sediment Relationships for Southwestern Ponderosa Pine Watersheds[C]// Watershed Management Planning for the 21st Century. ASCE, 2014.

4. LIU W., WEI X., LIU S., LIU Y., FAN H, ZHANG M., YIN J., ZHANG M. How do climate and forest changes affect long-term streamflow dynamics? A case study in the upper reach of Poyang River basin. Ecohydrology. 8, 46, 2015.

5. JIAN S., ZHAO C., FANG S., YU K. Effects of different vegetation restoration on soil water storage and water balance in the Chinese Loess Plateau. Agricultural \& Forest Meteorology. 206, 85, 2015.

6. CABALLERO L.A., EASTON Z.M., RICHARDS B.K., STEENHUIS T.S. Evaluating the bio-hydrological impact of a cloud forest in Central America using a semidistributed water balance model. Journal of Hydrology \& Hydromechanics. 61, 9, 2013.

7. FARLEY K.A., JOBBAGY E.G., JACKSON R.B. Effects of afforestation on water yield: a global synthesis with 
implications for policy. Global Change Biology. 11, 1565, 2005.

8. SUN G., ZHOU G., ZHANG Z., WEI X., MCNULTY S.G., VOSE J.M. Potential water yield reduction due to forestation across China. Journal of Hydrology. 328, 548, 2006.

9. WANG Y.H., YU P.T,. KARL-HEINZ FEGER, WEI X.H., SUN G., MIKE BONELL, XIONG W., ZHANG S.L., XU L.H. Annual runoff and evapotranspiration of forestlands and non-forestlands in selected basins of the Loess Plateau of China. Ecohydrology. 4, 277, 2011.

10. DOMINGO F., VILLAGARCIAL., BOER M.M., ALADOSARBOLEDAS L., PUIGDEGABREGAS J. Evaluating the long-term water balance of arid zone stream bed vegetation using evapotranspiration modelling and hillslope runoff measurements. Journal of Hydrology. 243, 17, 2016.

11. LIU Q., YANG Z., LIANG L., NAN W. Do changes in climate or vegetation regulate evapotranspiration and streamflow trends in water-limited basins?. Journal of Liaoning Technical University. 11, 11183, 2014.

12. MATIN M., BOURQUE P.A. Influence of Vegetation Cover on Regional Evapotranspiration in Semi-Arid Watersheds in Northwest China [M]// Evapotranspiration - An Overview. 2013.

13. ZHANG L., DAWES W.R., WALKER G.R. Response of mean annual evapotranspiration to vegetation changes at catchment scale. Water Resources Research. 37, 701, 2001.

14. LUO Y., XU L., RYSZ M., WANG Y., ZHANG H., ALVARES P. Occurrence and Transport of Tetracycline, Sulfonamide, Quinolone, and Macrolide Antibiotics in the Haihe River Basin. China. Environmental Science \& Technology. 45, 1827, 2011.

15. ZHAO X., YANG H., YANG Z., CHEN B., QIN Y. Applying the Input-Output Method to Account for Water Footprint and Virtual Water Trade in the Haihe River Basin in China. Environmental Science \& Technology, 44, 9150, 2010.

16. BAO Z., ZHANG J., WANG G., FU G., HE R., YAN X., JIN J., LIU Y., ZHANG A. Attribution for decreasing streamflow of the Haihe River basin, northern China: Climate variability or human activities? Journal of Hydrology. 460-461, 117, 2012.

17. SUN G., MCNULTY S.G., LU J., AMATYA D.M., LIANG Y., KOLKA R. Regional annual water yield from forest lands and its response to potential deforestation across the southeastern United States. Journal of Hydrology. 308, 258, 2005.

18. WEI W., CHEN L., ZHANG H., CHENG J. Effect of rainfall variation and landscape change on runoff and sediment yield from a loess hilly catchment in China. Environmental Earth Sciences. 73, 1005, 2015.

19. FANG H., SUN L., TANG Z. Effects of rainfall and slope on runoff, soil erosion and rill development: an experimental study using two loess soils. Hydrological Processes. 29, 2649, 2015.

20. DONG L., XIONG L., LALL U., WANG J. The effects of land use change and precipitation change on direct runoff in Wei River watershed, China. Water Science \& Technology. 71, 289, 2015.
21. AMARASINGHA R., SURIYAGODA L., MARAMBE B., GALAGEDARA L., SILVA G. Modelling the impact of changes in rainfall distribution on the irrigation water requirement and yield of short and medium duration rice varieties using APSIM during Maha season in the dry zone of Sri Lanka.[J]. Tropical Agricultural Research. 26, 274, 2015.

22. HUXMAN TRAVIS E., WILCOX BRADFORD P., BERESHEARS DAVID D., RUSSELL L., KEIRITH A., ERIC E., KEVIN H, WILLIAM T., ROBERT B. Ecohydrological Implications of woody plant encroachment. Ecology. 86, 308, 2005.

23. ZHAO W.Y., CHEN Y.N., LI J.L., JIA G. Periodicity of plant yield and its response to precipitation in the steppe desert of the Tianshan Mountains region. Journal of Arid Environments. 74, 445, 2010.

24. MINHAS P.S., DAGAR J.C. Use of Tree Plantations in Water-table Drawdown and Combating Soil Salinity[M]// Agroforestry for the Management of Waterlogged Saline Soils and Poor-Quality Waters. Springer India. 2016.

25. YUE W., WANG T., FRANZ T.E., CHEN X. Spatiotemporal patterns of water table fluctuations and evapotranspiration induced by riparian vegetation in a semiarid area. Water Resources Research. 52, 1949, 2016.

26. MALLICK K., TREBS I., BOEGH E., GIUSTARINI L., SCHLERF M. Canopy-scale biophysical controls of transpiration and evaporation in the Amazon Basin. Hydrology \& Earth System Sciences. 39, 897, 2017.

27. PEREIRA F.L., VALENTE F., DAVID J.S., JACKSON N., MINUNNO F. Rainfall interception modelling: Is the wet bulb approach adequate to estimate mean evaporation rate from wet/saturated canopies in all forest types? Journal of Hydrology. 534, 606, 2016.

28. PEEL M.C., MCMAHON T.A., FINLAYSON B.L. Vegetation impact on mean annual evapotranspiration at a global catchment scale. Water Resources Research. 46, W09508, 2010.

29. LIU X., LIU W., XIA J. Comparison of the streamflow sensitivity to aridity index between the Danjiangkou Reservoir basin and Miyun Reservoir basin, China. Theoretical and Applied Climatology. 111, 683, 2013.

30. MAX., XU J., NOORDWIJK M.V. Sensitivity of streamflow from a Himalayan catchment to plausible changes in land cover and climate. Hydrological Processes. 24, 1379, 2010.

31. WEI X., ZHANG M. Quantifying streamflow change caused by forest disturbance at a large spatial scale: A single watershed study. Water Resources Research. 46, 439, 2010.

32. WANG Y.H., YU P.T., KARL-HEINZ FEGER, WEI X., SUN G., MIKE B., WEI X., ZHANG S., XU L. Annual runoff and evapotranspiration of forestlands and nonforestlands in selected basins of the Loess Plateau of China. Ecohydrology. 4, 277, 2011.

33. ZHENG H., ZHANG L., ZHU R., LIU C., SATO Y., FUKUSHIMA Y. Responses of streamflow to climate and land surface change in the headwaters of the Yellow River Basin. Water Resources Research. 45, 641, 2009. 